\title{
イオン強度と $\mathrm{pH}$ による酵母分離蛋白質中の核酸の除去
}

\author{
浅 野 三夫*柴 崎 一 雄* \\ Reduction of Nucleic Acid in Isolated Yeast Protein by Adjusting \\ Ionic Strength and $\mathrm{pH}$ Value
}

Mitsuo Asano* and Kazuo Shibasaki*

\begin{abstract}
Methods for reducing the content of nucleic acids in isolated yeast protein were investigated. Isolated yeast protein prepared by acid precipitation of the extracted protein vibrogen cell mill contained about $10 \%$ of nucleic acid. The influence of ionic strength and $\mathrm{pH}$ value on the content of nucleic acids in the isolated protein was studied. Ionic strength 2.0 and pH 6-7 gave the most suitable condition for reduction of nucleic acid in the isolated protein. Under the condition, most of nucleic acid remained in the supernatant. The content of nitrogen and nucleic acids of the precipitated protein was 12.5 and $1.6 \%$, respectively.
\end{abstract}

(Received Mar. 24, 1980)

促来，醉母から分離蛋白筫を調製するには，細胞壁を 種々の方法で破砕して得た抽出液から等電点沈でえ (pH 4.0)で蛋白質を分離している。この分離蛋白質は 約:10\% の核酸を合えでいるために，蛋白質食品萦材と して好ましくないむのと判断され，より低い核酸含量の 蛋白質の分離法の開発が期待されている。

これまでの核酸の除去について，フルカリ119加熱(1)，

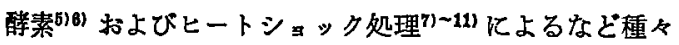
の試みが報告されているが，このような核酸除去処理に は蛋白質の变性を伴い，物性の变化するととが多く，さ らに経诸性を考虑すると必ずしる最善な方法とは考えに くい。そこで醉母蛋白質と核酸の溶解度におよほす $\mathrm{pH}$ とイオン強度の影響を検討した結果, 両成分の溶解挙動 に差巽のあるととを見出し，乙の差異を利用して新たに 蛋白質の变性の少ない，経済的にもすぐれた分離蛋白質 を調製することができたので報告する。

\section{実 験 方 法}

\section{1. 酵母蛋白質の調製}

試料は前報(2)同侎，市販生パン酵母（中越イースト） を充分水洗して凍結乾燥したるのを用い蛋白質を抽出し
た。抽出方法は Fig. 1 に示したようにパォイブロゲン セルミルを用い，上記凍結乾燥酵を $0.4 \%(0.1 \mathrm{~N}) \mathrm{Na}$ $\mathrm{OH}$ 溶液に 5 \%になるように試料管に慜濁しそれれ 4倍 量の Glass beads (径 $0.3 \mathrm{~mm}$ ) を加之て密閉, 恒温槽上 $20^{\circ} \mathrm{C}$ りの水を循環させながら 20 分間振とうして細胞壁

Lyophilized Baker's Yeast (S. cerevisiae)

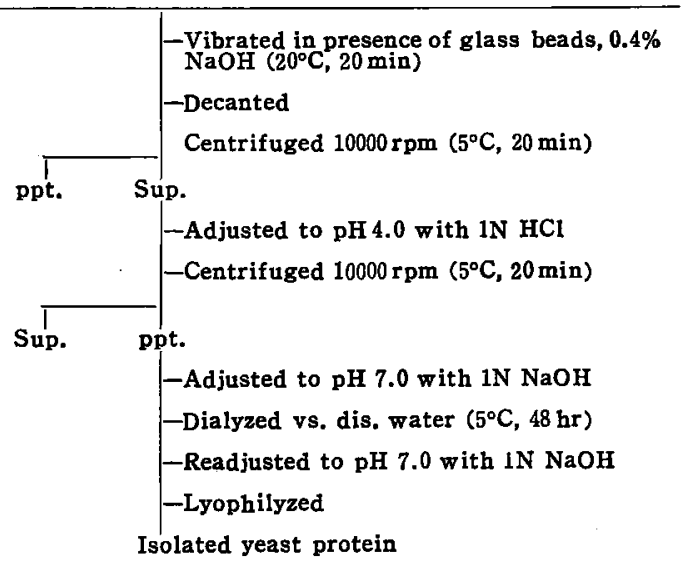

Fig. 1 Outline of protein extraction from baker's yeast

* 東北大学裳学部食粞化学科（广980 仙台市堤通雨宫町 1-1）

Department of Food Chemistry, Faculty of Agriculture, Tohoku University. Tsutsumidori

Amamiya-cho, Sendai-shi, Miyagi-ken 
破砕，蛋白質の抽出液定得， $\mathrm{pH} 4.0$ で等電点沈でえ 乙たものを醳母からの分離蛋白質とし，実験に供した。

\section{2. 窒素の定量}

前報同栐，常法の Semi micro Kjeldahl 法を用いた。

\section{3. 蛋白質の定量法}

前報同椂，常法の Biuret 法で蛋白質を定量した。

\section{4. 電気泳動}

前報12)同様䣷酸・尿素系のディスクポリアクリルフミ ドゲル䉓気泳動で行った。

\section{5. 核酸の定量}

前報同様オルシン塩酸法で定量を行った。

6. 溶解度

（1）濁度法

醉母の細胞を破确して蛋白質を抽出し，この抽出液を 各 $\mathrm{pH}$ に調整した時の濁度 $(570 \mathrm{~nm}$ の吸光度) で示し た。

(2) Biuret 法

上記同様に抽出乙，各 $\mathrm{pH}$ 汇調整後 10,000 r.p.m. 10 分間遠心分離し，その上澄中の蛋白質量を，Biuret 法 で定量した。

\section{7. イオン強度}

イオン強度の調製は半井化学(株)製特級塭化ナトリウ ム安用いて行った。

\section{実 験 結 果}

\section{1. 分離蛋白質の組成}

上記方法により䤉母から得た分離蛋白質の諸成分を分 析した結果 (Table 1) 約 70\% の蛋白質， $9.7 \%$ の核酸 を含んでいた。

Table 1 Component of isolated yeast protein

\begin{tabular}{lc}
\hline \multicolumn{1}{c}{ Component } & $(\%)$ \\
\hline Nitrogen & 12.02 \\
Protein & 69.5 \\
Nucleic acid (RNA) & 9.7 \\
Lipid* $^{*}$ & 12.3 \\
Moisture & 6.2
\end{tabular}

* Extracted with mixture of methanol and chloro. form $(1: 1)$

\section{2. 酵母蛋白質の溶解性}

（1）溶解性に予よほす $\mathrm{pH}$ の影㗽

前報で行った酵母蛋白質抽出液の $\mathrm{pH}$ による濁度変化 (Fig. 2) で明らかなように等電点沈でんまでの濁度挙動 （I）と等電点沈でえ後 $\mathrm{pH}$ を居した場合の渴度挙動(II) は全く異なり溶解度が著しくるるくなることを示した。

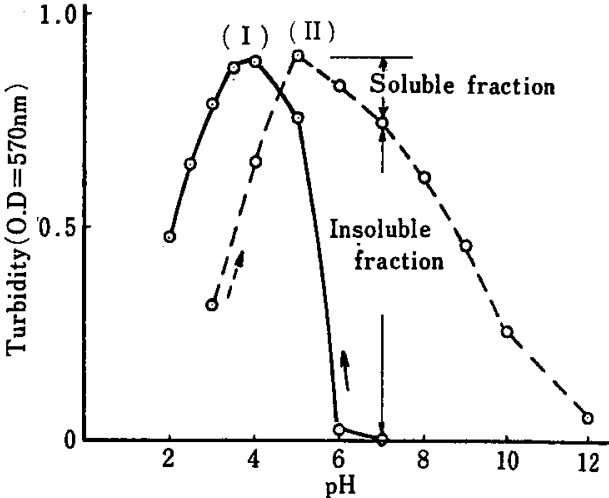

Fig. 2 Turbidity of total extract as a function of $\mathrm{pH}$

I (-O-): Change of turbidity (pH 12.0-2.0)

II $(. \circ \cdots)$ : Change of turbidity ( $\mathrm{pH} \mathrm{3.0-12.0)}$

このことは醉母蛋白啠が等電点沈でえ（pH 4.0) するこ とにより，酸に敏感で不溶化したか，あるいは $\mathrm{pH}$ 調整 時に塩が生成され，そのイオン強度の影響によることが 考えられる。

（2）溶解性におよほすイオン強度の影罄

Fig. 1 で示したように凍結乾燥しない試料を wet ppt, 透析して凍結乾燥したすのを, dry ppt とし,て れらの溶解性におよぼすイオン強度の影響を検討した。

Fig. 3(I) 溶解度曲線である。wet ppt の pH 7 㧍よび9では約 $80 \%$ の溶解度を示していたが，イオン強度が增すにつれ て溶解度が減少し，イオン強度 0.2 では $\mathrm{pH} 7$ で $20 \%$, pH 9 では $30 \%$ まで減少した。同様に dry pptでる pH 7 で $50 \%$ から $20 \%$ まで減少した。これらの結果は， イオン強度が醭母蛋白質の溶解性に大きな影響を与えて いることが明らかである。

\section{3. 核酸 (RNA) の溶解性}

酵母の蛋白質抽出液を $\mathrm{pH} 4.0$ で酸沈でんさせて得た 蛋白質中には，Table 1 で明らかなように，約 10\% の 核酸が含まれていることが明らかになったので，純精な 酵母 RNA を用いて，各 $\mathrm{pH}$ に和ける溶解度を調へた 結果がFig. 4 である。これらの結果から䤃母蛋白質の等 電点示す $\mathrm{pH} 4.0$ では RNA は単独では殆えど濁度を 示さず溶解状態であることを示しており, $\mathrm{pH} 4.0$ で酸沈 でえした蛋白質に $10 \%$ の㤥酸が含まれていることは， 最初から蛋白質と核酸が結合しており沈でんしたが，等 電点沈で九時に蛋白質と核酸が何らかの相互作用を叔こ 


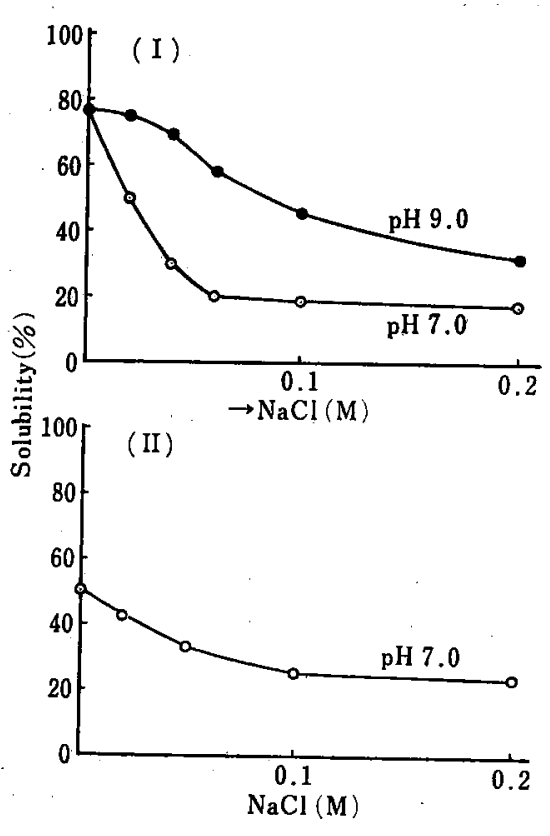

Fig. 3 Solubility of isolated protein as a function of ionic strength

I: Wet ppt.

I: Dry ppt. (lyophilyzed protein) $-\mathrm{O}-: \mathrm{pH} 7.0$

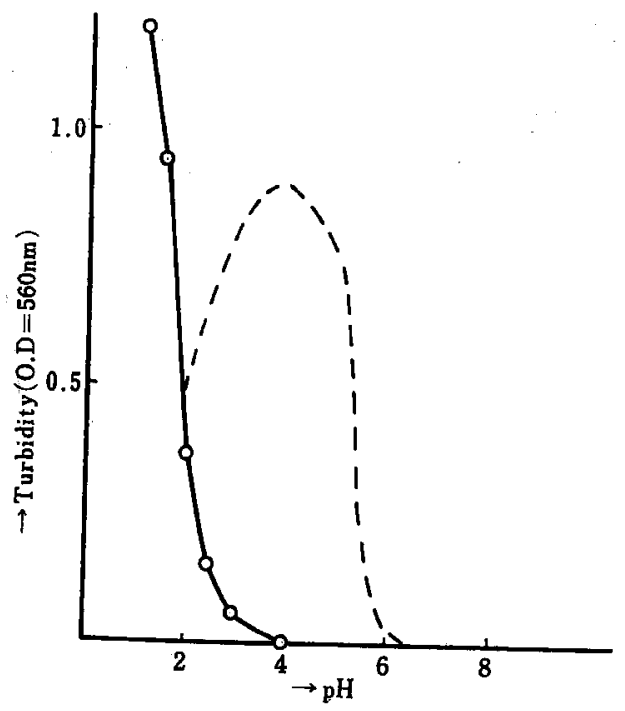

Fig. 4 Solubility of protein and RNA as a function of $\mathrm{pH}$

-O- Solubility of RNA $\quad$...... Solubility of protein
して沈でんしたものと考えられた。

\section{4. 醅母質と RNA との共沈現象}

上記のことを確認するために，脱核酸した醳母蛋白留 を純粋な酵母 RNA を用い， RNA（5 mg）に対する蛋 白質の割合を $1: 0,1: 1,1: 2,1: 5$, お上び $1: 10$ にしたものを $0.4 \% \mathrm{NaOH} 10 \mathrm{ml}$ にとかし, 各々 $\mathrm{pH}$ 4.0 に調整して遠心し，その上澄液の RNA 量を定量し た結果 (Fig. 5) RNA と蛋白の割合が 1:0では RNA は全く沈でんせず，RNA に対する蛋白質の量が增加す るに徒って沈でえする RNA 量も增加し，その比が 1 ： 10 では 95\%の RNAが蛋白質といっしょに沈でんして しまうことが明らかになった。丁ルカリ分解法による低 核酸会量の分離蛋白質の調製を試みた田島ら2) も乾燥菌 体に $0.2 \mathrm{NNaOH}$ 溶液を加え, $80^{\circ} \mathrm{C}$ 加熱抽出した時は 沈でえ区分低核酸含量の蛋白質を得るが， $37^{\circ} \mathrm{C}$ 抽出で は，核酸と蛋白質が，いっしょに沈でんすることを明ら かにし蛋白質と核酸との相互作用を示唆している。

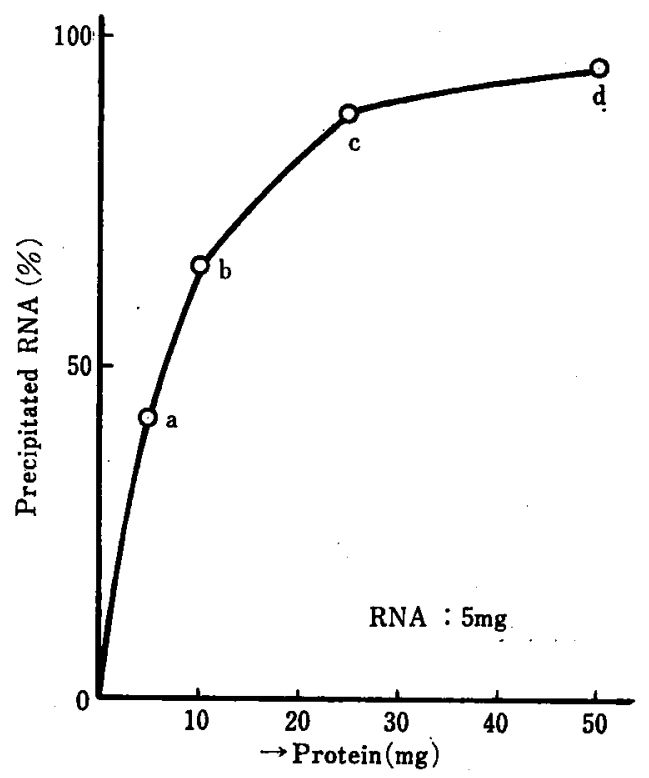

Fig. 5 Correlation between the amount of added protein and the precipitated RNA (\%)

Ratio of RNA and protein $(a: 5 / 5, b: 5 / 10, c: 5 / 25$, d : 5/50)

\section{5. 醂母の酸沈でん蛋白質より枝酸の分離}

Fig. 3 （I）（II）より醳母蛋白質は $\mathrm{pH} 7.0$ ，イオン 強度 0.2 の条件下では 75 80\% 以上が溶解しないこと が明らかである。しかしながらイオン強度 0.2 の条件で む蛋白質と共に沈でんした核酸は $\mathrm{pH}$ をてルカリ側に上 
げることによって溶解してくる。

䤃母の酸沈でん蛋白質を脱塩水に懸濁し， $1 \mathrm{~N} \mathrm{NaOH}$

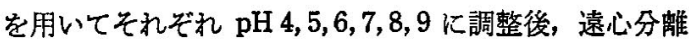
し，上登と沈でん区分に分け各々の核酸含量を調べた結 果を Fig. 6 に示した。pH を上げることによって上澄液 中の核酸含量が増加し，逆に沈でえ区分の核酸含量は減 少していった。このととは沈でえしていた核酸が $\mathrm{pH}$ 上げることによってとけ出し上隥区分に移行するととを 示している。しかし, $\mathrm{pH} 7.0$ 附近において上澄区分の核 酸合量がピークを示し, pH 7.0よりアルカリ側では減少

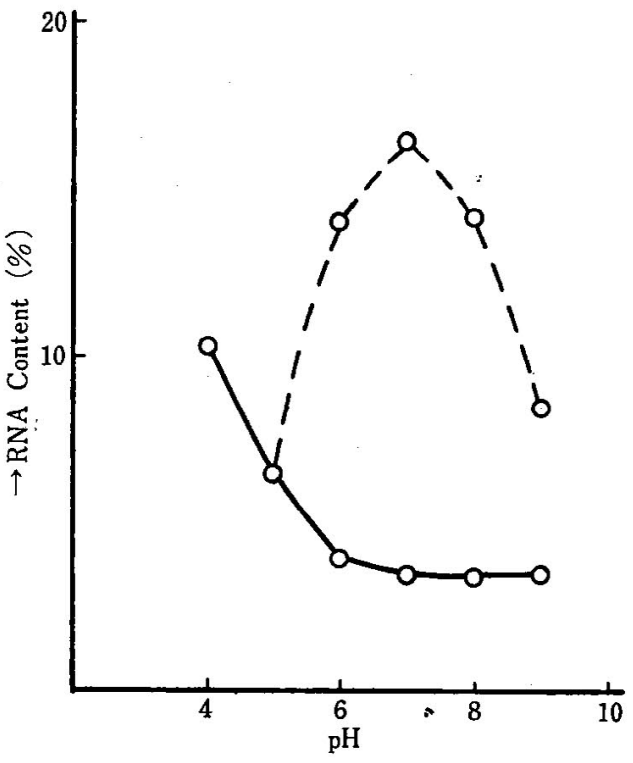

Fig. 6 Change of RNA content (\%) in isolated protein as a function of $\mathrm{pH}$

-O- RNA content in the precipitate

... $\mathrm{O}$. RNA content in the supernatant

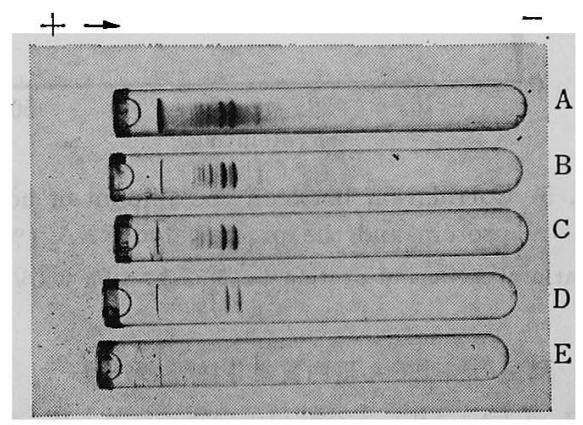

Fig. 7 Electrophoretic pattern of each dissolved protein fraction

(pH 7.0-pH 13.0)

A: pH 13.0, B: 10.0, C: 9.0, D: 8.0, E: 7.0

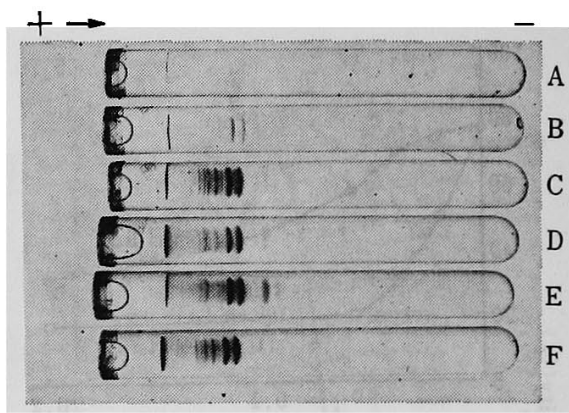

Fig. 8 Electrophoretic pattern of each precipitated protein

(pH 4.0-pH 9.0)

A: pH 9.0, B: 8.0, C: 7.0, D: 6.0, E: $5.0, \quad F: 4.0$

する傾向が見られた。これは $\mathrm{pH} か ゙$ 高くなることにより 沈でしていた蛋白質が溶けて上澄区分に移動し，相詨 的に核酸合量が減少したものと思われる。これらのこと

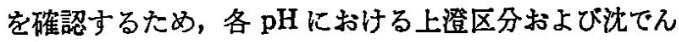
区分の電気泳動分析を行った結果 (Fig. 7〜8) pH 8.0 以 上になるに従って上澄区分江蛋白質のバンドが現われ， 逆沈でれ区分から減少していった。

\section{6. 核酸除去におよぼすイオン強度と $\mathrm{pH}$ の効果}

上記結果から蛋白質は沈でん状態で，共存している核 酸だけを溶かして除去するにはイオン強度と $\mathrm{pH}$ が関係

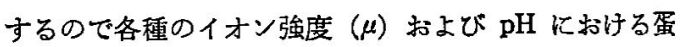
白質および核酸の溶解性を詳細に調べた結果を Fig. 9, 10 に示した。コントロールでは $\mathrm{pH}$ を上げることによ って溶解性も增し，pH 7.0 で約 $90 \%$ が溶解した。しか しイオン強度を 0.1 以上にすることによって蛋白質の溶 解性が著しく低下し， $\mu=0.1 て ゙ 28 \% ， \mu=0.3,0.5,1.0$ ではほぼ同程度で $24 \sim 27 \%, \mu=2.0$ では $15 \%$ しか谘解

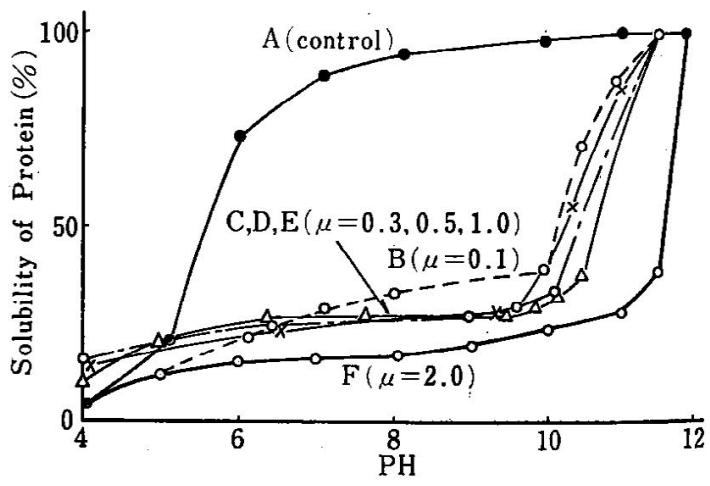

Fig. 9 Effect of ionic strength and $\mathrm{pH}$ on solubility of protein

A (-) - ) Control, B (-O--): $\mu=0.1$, C $(\cdots 0 \cdots)$ : 0.3 , D $(-\Delta-): 0.5, \mathrm{E}(-x-): 1.0, \mathrm{~F}(-\mathrm{O}-): 2.0$ 


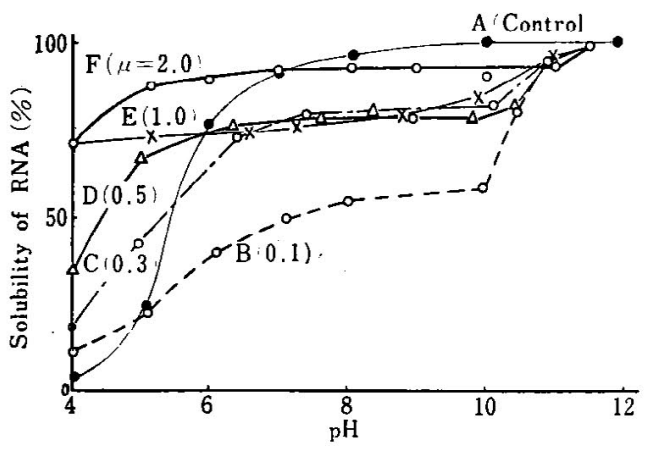

Fig. 10. Effect of ionic strength and $\mathrm{pH}$ on solubility of RNA

A (-๑): Control, B (--O--): $\mu=0.1, \quad$ C $(\cdots \circ \cdots)$ : $0.3, \mathrm{D}(-\Delta-): 0.5, \mathrm{E}(-\mathrm{X}-): 1.0, \mathrm{~F}(-\mathrm{C}-): 2.0$

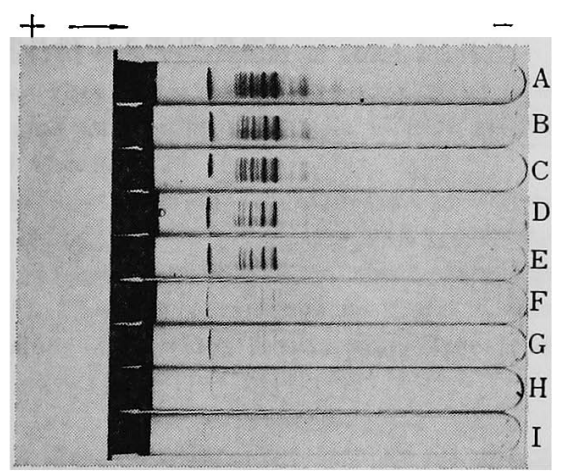

Fig. 11 Electrophoretic pattern of protein fraction dissolved with each ionic strength

A: Control, B: $\mu=0.001$, C: 0.01, D: 0.02, E: 0.05 , F: 0.1, G: $0.5, \mathrm{H}: 1.0$, I: 2.0

しなかった。これらの結果を確認するため，各イオン強 度（pH7.0）における上登区分を電気泳動的に調べた結 果 (Fig. 11) 溶解挙動と電気泳動的成分挙動は同じ傾向 を示し， $\mu=0.05$ までは蛋白質が鮮明なバンドとして現 れ, $\mu=0.1$ 以上では急激にバンドが薄くなり, $\mu=2.0$ ではパンドがほとえと確認できなかった。

これに対し，核酸はイオン強度を增すことによって溶 解性が堌加し， $\mu=2.0$ では，pH $7.0 て ゙$ 約 $90 \%$ 以上が 溶解することが明らかになった。

次に上記結果から核酸除去の最適条件を検討するため に蛋白質之核酸の $\mathrm{pH}$ による溶解挙動を各イオン強度別 に図示した。(Fig. 12) コントロールでは蛋白質と核酸 共に同じ挙動を示し核酸を除くことは不可能である。し かしイオン強度を增すことによって蛋白質と核酸の溶解 度の差が大きくなり $\mu=2.0$ では pH 5.0〜10.0 の広い
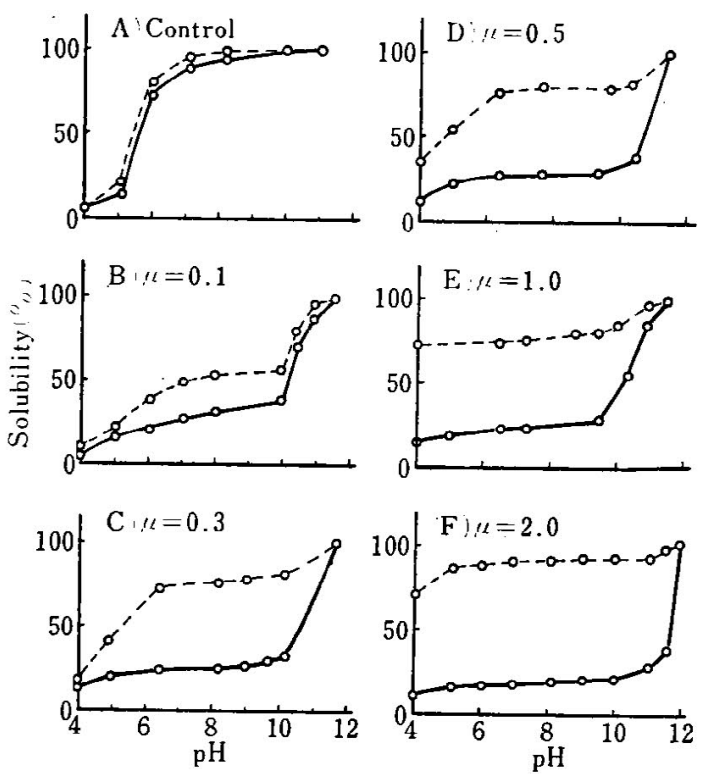

Fig. 12. Effect of ionic strength and $\mathrm{pH}$ on solubility of the protein and RNA

$-\mathrm{O}-$ : Change of solubility of protein by $\mathrm{pH}$ --O--: Change of solubility of RNA by $\mathrm{pH}$ A: Control, B: $\mu=0.1$, C: 0.3, D: $0.5, E: 1.0$ F: 2.0

Table 2 Component of isolated yeast protein after removing nucleic acid (RNA)

\begin{tabular}{lc}
\hline \multicolumn{1}{c}{ Component } & $(\%)$ \\
\hline Nitrogen & 12.50 \\
Protein & 76.9 \\
Nucleic acid (RNA) & 1.6 \\
Lipid ${ }^{*}$ & 11.8 \\
Moisture & 7.0 \\
\hline
\end{tabular}

* Extracted with mixture of methanol and chloro. form $(1: 1)$

$\mathrm{pH}$ 範囲で核酸を除くことが可能であり，とくに $\mu=2.0$ $\mathrm{pH} 6.0 \sim 7.0$ が蛋白質の損失が少なく最良の条件と思的 れた。

上記方法にて核酸除去処理它行った蛋白質の分析結果 を Table 2 に示したが，乾物あたり核酸含量 $1.6 \%$ で 除去前の約 85\% が除去出来た。

\section{要約}

酵母蛋白質は等電点沈でえすることによって約 $10 \%$ の核酸が蛋白質と共に沈でんしているが，これらの核酸 を簡単に除去する方法を検討した。 
（1）精製酵母 RNA を用いて等電点時の蛋白質と核酸 との相互作用を検討した結果，酵母蛋白質と RNAの比 が $10: 1$ の場合，加えた RNA の 95\% が蛋白質とい。 しょに共沈することが明らかになった。

（2）蛋白質および核酸の溶解性を詳細に調へ，蛋白質 は溶解せずに核酸のみ溶解するイオン強度 $(\mu)$ および $\mathrm{pH}$ 条件を検討した結果 $\mu=2.0, \mathrm{pH} 6 \sim 7$ が核酸除去 の最適条件であった。

（3）これらの方法で酵母蛋白質の核酸含量が，10\%か ら $1.6 \%$ と約 $85 \%$ 除去することが出来た。

文献

1) 満田久輝 - 河合丈雄・壬生 良・鹿内健彦：栄窟 之食糧， 17，34 (1964).

2) Tajima, M. and Yoshikawa, S.: Agric. Biol. Chem., 39, 611 (1975).

3) Hendenskog, G. and Ebinghaus, L.: Biotech. Bioeng., 14, 447 (1972).
4) Vananuvat P. and Kinsella, E.: J. Agric. Food Chem., 23, 216 (1975).

5) Castro, A.C., Sinsky, A.J. and Tannenbaum, S.R.: Appl. Microbiol., 22, 422 (1971).

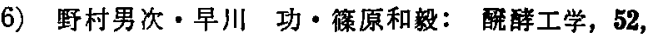
35 (1974).

7) Maul, S.B., Sinskey, A.J. and Tannenbaum, S.R.: Nature, 228, 181 (1970).

8) Ohta, S., Maul, S. and Sinskey, A.J., TannenвaUm, S.R.: Appl. Microbiol., 22, 415 (1971).

9) Tajima, M. Yoshikawa, S.: Xth and International Congress of Nutrition, Kyoto (1975).

10) ZeE, J.A. and Simard, R.E.: Appl. Microbiol., 29, 59 (1974).

11）芝崎 勲・安川照雄・浅田洋司：日食工誌, 21, 545 (1974).

12）浅野三夫・佐藤 宣・柴崎一雄：日食工誌，27, 172 (1980).

(昭和 55 年 3 月 24 日受理)

\section{新 刊紹 介}

人間の栄著における食用油脂の役割

FAO/WHO 合同䡎門家委員会報告 金田尚志監訳

1977 年 9 月 21 30日，ローマにおいて行なわれた FAO/WHO 合同専門家委貝会の 報告の邦訳である。目 次を示すと次のとうりである。

1. 定 義

2. エネルギー源としての脂肪

3. 成人と小児の食物における油脂の利用

4. 必須脂肪酸

5. 発育初期における必須脂肪酸の役割。
6. 心臟疾患，肥満および糖尿病の予防之治療におけ る油脂の役割

7. 油脂の栄養洒に及ぼす加工処理の影響

8. 特別考虑事項

9. 油脂の生産，流通および消費に関する最近の傾向

10. 油脂の品質と組成に 及ほす動植物の育㮔と管理の 影響

11. 勧 告

書物の表題から与える印象は，本書の内容が行政的勧 告のように思光るが，実際は，油脂に関する最近の研究 の紹介に近い。参考交献も227.と多く, 油脂の加工, 栄 业の研究者にとって有用である。

\section{$A 5$ 版 99 頁}

医歯蒋出版 2,000 円 